\title{
Competencies for educational actions of Family Health Strategy nurses
}

\author{
Competências para ação educativa de enfermeiras da estratégia de saúde da família \\ Competencias para la acción educativa de las enfermeras de la estrategia de salud de la familia
}

\section{Valéria Marli Leonello', Milene Pires de Moraes Vieira', Thalita Cristine Ramirez Duarte'}

'Universidade de São Paulo, School of Nursing. São Paulo, Brazil.

\section{How to cite this article:}

Leonello VM, Vieira MPM, Duarte TCR. Competencies for educational actions of Family Health Strategy nurses. Rev Bras Enferm [Internet]. 2018;71(3):1072-8. DOI: http://dx.doi.org/10.1590/0034-7167-2017-0390

Submission: 06-09-2017

Approval: 08-14-2017

\begin{abstract}
Objective: To create competencies for the educational actions of nurses in the care and management work processes at the Family Health Strategy. Method: This is an exploratory, descriptive research, with a qualitative approach, on nurses of the Family Health Strategy (FHS) from a municipality in the Greater São Paulo. It was performed through semi-structured interviews and workshops. Results: There is a set of specific competencies for the educational actions of the nurse in care work, geared towards meeting the health needs of users/community; and for educational actions in management work, focused on work organization of the health team, indicating the importance of this work to FHS. Final considerations: Creating competencies proved to be significant to reflect on the educational actions of the FHS nurses and can be used as a strategy in permanent education processes.
\end{abstract}

Descriptors: Primary Health Care Nursing; Nurses of Family Health; Health Education; Professional Competency; Competencybased Education.

\section{RESUMO}

Objetivo: Construir competências para ação educativa de enfermeiras no processo de trabalho assistencial e gerencial na Estratégia Saúde da Família. Método: Pesquisa exploratória, descritiva, com abordagem qualitativa de enfermeiras da Estratégia Saúde da Família (ESF), de um município da grande São Paulo, por meio de entrevistas semiestruturadas e oficinas de trabalho. Resultados: Há um conjunto de competências específicas para a ação educativa da enfermeira no trabalho assistencial, voltado ao atendimento das necessidades de saúde dos usuários/comunidade, e para a ação educativa no trabalho gerencial, com foco na organização do trabalho da equipe de saúde, indicando a importância desse trabalho no contexto da ESF. Considerações finais: A construção de competências mostrou-se significativa para refletir sobre as ações educativas das enfermeiras na ESF, podendo ser utilizada como estratégia em processos de educação permanente.

Descritores: Enfermagem de Atenção Primária; Enfermeiras de Saúde da Família; Educação em Saúde; Competência Profissional; Educação Baseada em Competências.

\section{RESUMEN}

Objetivo: Construir competencias para la acción educativa de las enfermeras en el proceso de trabajo asistencial y gerencial en la Estrategia de Salud de la Familia. Método: La Investigación exploratoria, descriptiva, con el abordaje cualitativo de enfermeras de la Estrategia de Salud de la Familia (ESF), de un municipio de la gran ciudad de São Paulo, por medio de encuestas semiestructuradas y talleres de trabajo. Resultados: Hay un conjunto de competencias específicas para la acción educativa de la enfermera en el trabajo asistencial, dirigido a la atención a las necesidades de salud de los usuarios/la comunidad, y para la acción educativa en el trabajo gerencial, con enfoque en la organización del trabajo del equipo de salud, indicando la importancia de ese trabajo en el contexto de la ESF. Consideraciones finales: La construcción de competencias se mostró significativa para reflejar sobre las acciones educativas de las enfermeras en la ESF, pudiendo ser utilizada como estrategia en los procesos de educación permanente.

Descriptores: Enfermería de Atención Primaria; Enfermeras de Salud de la Familia; Educación en Salud; Competencia Profesional; Educación Basada en Competencias. 


\section{INTRODUCTION}

This study takes, as an object of investigation, the educational actions developed in the care and management work processes by nurses of the Family Health Strategy (FHS), especially regarding the competencies to such action.

We start from the premise that the work process in nursing has a double dimension: the care and the management. In the first, the intervention objects are the needs for care, aiming the integral attention to subjects and collectives. The second, in turn, has as an object the work organization, aiming to create, and effect adequate work conditions for workers and adequate care conditions to assisted subjects and collectives ${ }^{(1)}$.

Educational actions have a fundamental role in primary health care, which have the FHS as the main reorganization model for this level of care ${ }^{(2)}$. These actions also permeate all the care work of nurses, such as in nursing consultations, home visits to families, and group activities performed at health units and the attached territory ${ }^{(3)}$. In managerial work, the educational role of nurses in teamwork organization is highlighted in the Unidades Básicas de Saúde (Basic Health Units - UBS) as well as on permanent education activities for nursing teams and Agentes Comunitários da Saúde (Community Health Agents - ACS).

Although considered an attribution of nurses in the FHS, the educational actions developed in care and management dimensions historically focus on action verticalization. Thus, the actions are performed for (and not with) the subjects involved in the process, whether they are users or professionals of the team ${ }^{(4-6)}$.

Studies on this theme show that educational actions of the care dimension focus on disease and on behavior changes, bringing to the spotlight the blame on the subject, and the absence or scarcity of dialogue among those involved in the process ${ }^{(7-9)}$.

On the other hand, the educational actions are advocated as an opportunity to listen, dialogue, share different knowledge, and collectively construct ways to address issues related to health-disease processes, in response to the health needs of subjects and collectives. In Brazil, since the 1970s, experiences of popular education in health brought this perspective of education to health services, especially those of primary health care ${ }^{(10-12)}$.

For the development of educational actions by health professionals in these guidelines, a formative process ${ }^{(13)}$ is required to make them close to this perspective. A possible starting point is creating professional competencies concerning the educational actions.

"Competency" is here understood as the articulated set of knowledge (learning to know, learning to do, learning to live with others, and learning to be) needed to cope/solve a situation. To create it, it is necessary to identify such knowledge from the actions that compose the day-to-day of professional practice ${ }^{(14-15)}$.

Thus, the guiding question of the research was: Which are the competencies for educational actions developed in the care and management work of the FHS nurses?

\section{OBJECTIVE}

Creating competencies for the educational actions, in the care and management work of the FHS nurses.

\section{METHOD}

\section{Ethical aspects}

All ethical procedures were respected, based on resolution no. 466/12. The project was presented to all the nurses, explaining the importance of participants' collaboration in deepening and understanding the theme, and clarifying the freedom and voluntariness of participation, with no kind of prejudice or sanction. All the nurses who agreed in participating received an informed consent form and agreed in signing it. The research project was approved by the Research Ethics Committee of the School of Nursing of the University of São Paulo.

\section{Theoretical-methodological framework}

This is a descriptive, exploratory research, with a qualitative approach. Notions of competency ${ }^{(14)}$, popular education in health ${ }^{(12)}$, and the four knowledge necessary to the Future Education ${ }^{(15)}$ were the conceptual categories.

"Competency" means the ability to activate distinct knowledge to solve a particular situation. Hence, it is essential to investigate the routine of the professional actions to identify the set of competencies ${ }^{(14)}$.

Regarding health education, although with different conceptual aspects, it is advocated as a strategy to encourage users' participation in health services, binding their knowledge and experiences to those of the health professionals ${ }^{(12)}$.

The four postulated knowledge on the Report of the International Commission on Education for the Twenty-first Century are considered guiding shafts for an education that aims at a common project. They are: Learning to know refers not only to knowledge acquisition, but also to the domain of the instruments in the cognitive sphere. Learning to do articulates and combines the technical preparation with personal and relational aptitudes, which involves, inter alia, initiative and decision-making on various situations of the professional practice. Learning to live together, learning to live with others considers the importance of interdependence among humans, thus it needs to be analyzed. Learning to be implies in commitment and social engagement of the worker in relation to its reality, recognizing itself as a subject who can transform and improve such reality ${ }^{(15)}$.

\section{Study scenario}

The research occurred in Embu das Artes, in the metropolitan region of São Paulo. Study locations were composed of 11 UBS with FHS. This choice considered the Human Development Index (HDI) of the municipality, which is close to the Brazilian reality, and the convenience criteria, since it was more accessible to the researchers.

\section{Data source}

The study subjects were 15 nurses of the FHS primary health care. Participants' inclusion criteria were to be working for at least six months on the FHS and to perform educational actions during the work routine. Exclusion criteria were to be on vacation or on work leave. 


\section{Data collection and study steps}

Data were collected in two steps. The first step was through semi-structured interviews with 15 nurses, and a script with the following issues: 1) How is your work as a nurse in the unit? 2) Considering the work you just detailed, how are inserted the educational actions (with users and workers) developed by nurses? Which are them, how do they work? 3) What kind(s) of knowledge is(are) necessary for the nurse to develop them? What does the nurse must learn to know, to do, to be, and to live with to develop them? This step resulted in two domains of knowledge: one related to the care dimension, and the other regarding the managerial dimension of work of the FHS nurse.

In the second step, workshops were used $^{(16)}$ - sequential encounters with a general thematic, enclosed, and presented -, allowing the subjects voluntary participation in the reflecting and deepening on the theme of the discussion. From the reports, a debate shall be encouraged, to share lived experiences and knowledge. About the competencies, workshops are relevant and important since from these experiences the nurses could discuss and identify the competencies related to the educational action developed at FHS.

Three workshops were held (Chart 1), with an average duration of 2 hours each. The 15 interviewed nurses were invited to participate in the workshops, to validate the interviews material and to collaborate with the creation of competencies for educational actions from their professional activities.

Six nurses agreed and were willing to participate in this step. The first step occurred in the second half of 2014, and the second, from June to July 2015.

In the first workshop, we worked on aspects of health education and competencies in the used reference. The nurses received the material analyzed in the interviews of the first step, to validate it and to collaborate in the building of competencies. Dynamics were mediated by a researcher with experience in conducting workshops, based on studies about it ${ }^{(16)}$.

The second workshop was attended by three nurses. One absence was due to illness, and the two other absences were not justified. We decided to proceed with the workshop, even with a small number of participants, valuing the nurses who showed up. They finished the competencies for educational actions in the care dimension, since its construction demanded more time.

Finishing the second step, the third workshop had five nurses, with one absence due to illness. In the workshop were built competencies for educational actions in the managerial dimension. Throughout the process, we prized the dialogue and the nurses' active participation through discussions, reports, and experiences brought by them.

\section{Data analysis}

Discourse analysis ${ }^{(17)}$ was used to examine the research material. From the interviews, thematic phrases were identified, organized, and categorized according to the knowledge postulated in the Report of the International Commission on Education for the Twenty First Century: learning to know, learning to do, learning to be, and learning to live with others ${ }^{(15)}$. We highlight the knowledge were explained by the researchers before the interviews, to facilitate the participants understanding. For the second step, the competencies were built from collective construction with the nurses who were present.

\section{RESULTS}

After the identification of knowledge resulting from interview analysis, it was possible to discuss and reflect on the workshops. This resulted in a previous set of competencies, submitted to discourse analysis, and approximated to the theoretical reference. Two charts were designed from it: one on the competencies for educational actions in the care and management works of the FHS nurses (Chart 2); and another on the competencies common to both dimensions: care and management, of the FHS nurses (Chart 3).

On the care dimension, the nurses consider the need to integrate health care, to develop pedagogical strategies for groups, to evaluate the educational process, and to practice the intersectoral approach.

In the managerial dimension were listed: the need for an environment to share ideas and doubts, planning the educational 
actions with the team professionals, developing sharing leadership abilities, and for processional evaluations on the educational process held.

It also exists a set of competencies common to care and management dimensions of the nursing work, showing that, although with different aims, both care as management share common characteristics. Besides, both are directly linked to the health education reference proposed ${ }^{(12)}$.

From the nurses' perspective, another important aspect complements the competencies approach: the support and institutional appreciation for conducting educational actions in the adopted perspective. There have been reports of shortage and/or inadequacy of materials and physical space, as well as the need for educational strategies with the health team, dedicated to this thematic. Although they constitute a reality of the health services, such difficulties were incorporated into the educational actions.

\section{DISCUSSION}

Regarding competencies for educational actions in the care dimension, we highlight the need for integrating the care in all the life cycles. To think of educational actions that recognize the user as a holistic being and, at the same time, social, inserted in a context, expressed by its social inclusion (work, income, services access, and rights). Thus, making integrality a guiding axis of all the educational actions developed in health services ${ }^{(18-19)}$.

Educational groups compose the set of practices of health units and, for them to be implemented, it is necessary to develop pedagogical strategies. The experience exchanges, conversation groups, and problematization are examples of strategies to develop this competency, provided that they are based on popular health education, with planning and development of educational activities ${ }^{(20)}$.

Considering the integrality of health actions, it is necessary to think of intersectoral actions that expand the collaboration among the FHS professionals and other sectors such as education and culture. This requires that the nurse knows to practice the intersectoral approach, enabling spaces for sharing of decisions among the distinct institutions, in different health sectors, encouraging horizontal relations between partners and interdependence of services. It also demands social participation, since it integrates the community in which is inserted ${ }^{(21)}$.

In addition, the nurses observe the need for evaluating the educational actions with users/groups/families and collectivity, which refers to the need for explaining the educational reference used and for planning the educational actions, with expected results and objectives, in short, medium, and long terms. We highlight the importance of the evaluation having indicators of educational actions that are consistent with the educational reference used ${ }^{(22)}$.

Concerning the managerial dimension, it is observed the need for an environment to share ideas and doubts. Since the health work is done in a collective manner with subjects that comprise the health teams, it is essential to have an environment where the team identity and the objectives to share are constructed, since these are fundamental elements of joint work ${ }^{(23)}$.

The staff meeting is an empowering strategy, since it facilitates the communication and creates a powerful space for the sharing of ideas and the reflection on everyday practices; hence, contributing to organize measures, plan actions, and make decisions for the work to be put into practice ${ }^{(24)}$. For this integration to happen, it is necessary that health professionals recognize their specific roles, roles which are common to everyone in the team, and the ones that require coordination and collaboration.

Also necessary is the planning for educational actions with health team professionals, in such a way that the nurses have time to think and elaborate their activities with the team. The Situational Strategic Planning (SSP) is a management tool that may help defining the problems in a health unit, identifying causes and subjects involved, and proposing a participatory planning of actions to address them. We highlight this planning should be used in a dialogical and participatory perspective, involving the team in the process ${ }^{(21)}$.

According to Ano et al. ${ }^{(25)}$, the leadership ability shared within the team is the most requested general competency and, to meet this need, spaces to reflect and enhance professional practices are needed. Actions based on permanent education are indicated because they propel the personal growth and professional development of the subjects.

As healthcare organizations are complex, the nurse needs the development of a team to have institutional support. Actions related to professional development should be documented to be visible in the organizations, through a participatory management that shares power relations; thus, sensitizing 
the individuals regarding the responsibility in their improvement and the sharing of new knowledge ${ }^{(22)}$.

Processional evaluations constitute a relevant managerial tool and allow to the nurse the knowledge on potential and frailties of the professionals. The evaluation process identifies the need for training and developing the team, formulates the assistance strategies provided, and organizes the health unit. Health institutions have strived to reshape the professional development, aiming to use it as a resource for the personal improvement of the workers and to understand how they experience this process ${ }^{(25)}$.

It should be noted that instruments, such as planning, leadership, and communication, only make sense provided they are operationalized to meet the health needs. Hence, they are consistent with the principles of integrality and teamwork of basic attention and FHS. Such instruments must be used in a dialogical and participatory perspective, with stimuli to the shared leadership and team participation, from the identification to the collective construction to face health problems.

In line with this perspective, the educational activities developed by the FHS nurse are important to the process assertiveness. In addition to courses and training towards specific gaps of technical and scientific knowledge, it is necessary to renew the place and the sense of educational actions developed with the team. Such actions are fundamental to discuss and reflect on the healthcare work. From them, it is possible to bring changes and transformations that actually move the activity logic from services production to care production.

On the competencies for educational actions in the care dimension (Chart 2), the first one of them is to identify the health needs of users, families, and collectivity and the needs for formation/education of the health team professionals. This implies in recognizing the needs as a starting point to plan the educational actions related to the care and management dimensions, aiming to overcome the persistence of actions which disregard or do not listen properly the health needs of the involved subjects ${ }^{(7)}$.

In addition to identifying the health needs of users and the education needs of professionals, it is fundamental to value the experiences of users, families, collectivity, and professionals, considering these subjects as everyday specialists, greatly contributing to the planning and development of the educational process. Traditionally, the educational actions overevaluate the professional knowledge at the expense of knowledge expressed by the subjects' experiences. That puts under discussion the proposition of educational actions conducted with subjects, and not for them ${ }^{(4-12)}$.

Communication flows, in turn, were pointed by the nurses as something important and still lacking in the educational actions developed at FHS. Information on the work process organization in the units often do not properly reach users and health professionals, which may cause conflicts and difficulties in the development of educational actions. In addition, the flow construction could also involve more the users and professionals, not limiting to the management of nurses. Thus, the proper and easy access to information would be possible, without hindering or limiting the subjects' actions, considering the dynamism and complexity of the issues brought by users and professionals ${ }^{(26)}$.
Several actions are planned with the population, resuming here the importance of stimulating the social control and its articulation with the health team as an essential element in popular health education that, similarly to care integrality, is a principle to be guaranteed by the Sistema Único de Saúde (Brazilian Unified Health System - SUS). Study participants report the need to strengthen the articulation between social control and health team, which shows a frailty in this relation - often contentious and misunderstood by those involved in it ${ }^{(27)}$.

It is necessary to reinforce to health professionals the role of social participation as a right and, at the same time, reiterate to users' representatives that such role can only be built through dialogue, considering the services reality and the purpose of the FHS. Therefore, the investment in proposals that reiterate such collective responsibility both to health team and users is of foremost importance, thus implementing them in local, municipal, and regional councils, and increasing social participation that is mediated by educational actions.

\section{Study limitations}

Workshops, as a methodological strategy, proved to be efficient to create competencies of the FHS nurses. It was observed that the listed competencies align with the SUS perspective, especially regarding the care integrality, the service provided regarding the needs, the social control, and the intersectoral approach.

However, it was also possible to observe that, although existing, the popular health education is still fragile in nursing work. Such aspect was problematized in the workshops, which lead the nurses to reflect on their educational actions.

Given the theoretical reference we adopted, a study limitation was that the workshops were only with nurses. Certainly, deepening studies on the other subjects, including from the gender perspective, is very important. Among these subjects yet to be studied, we highlight the other health team professionals and the users. This requires planning to adapt the strategies used in the workshops for these different subjects.

\section{Contributions to the fields of nursing and primary health care}

The listed competencies refer to a particular context of the FHS, and the creation of such process has shown the importance in stimulating the reflection of nurses on the educational actions they perform. Thus, to have a set of competencies contributes as much to show the educational work already done, as to guide the development of future educational actions that promote the perspective of popular educational health in education processes of the FHS nurses.

\section{FINAL CONSIDERATIONS}

The created competencies are fundamental for educational actions, on care and management dimensions, of the FHS nurses. In the education perspective adopted, these competencies can promote discussion spaces and approximate the users and health team, in addition to increasing the proximity among team professionals. It is still necessary to break with the reductionist and vertical approach of the 
educational actions, moving to a broader and more critical vision, which allows spaces in which health care is collectively constructed, including users, families, communities, and team workers.

A set of competencies that are common to educational actions in care and management dimensions can be observed. In other words, the educational actions developed with the team should be directly related to those developed with the users, following the same principles of participation, dialogue, respect, and attention that aim at health needs.
Finally, simply stating the competencies for educational actions does not imply in changes or transformations in the healthcare practice. However, the process of creating them through workshops proved to be important for the reflection of nurses on their own educational process, at and for their work; hence, it can be considered a permanent education strategy in the FHS.

\section{FUNDING}

Aid to Research, Fapesp process no. 2013/025052

\section{REFERENCES}

1. Hausmann M, Peduzzi M. Articulação entre as dimensões gerencial e assistencial do processo de trabalho do enfermeiro. Texto Contexto Enferm [Internet]. 2009[cited 2017 Aug 08];18(2):258-65. Available from: http://www.scielo.br/pdf/tce/v18n2/08.pdf

2. Brasil. Ministério da Saúde. Política Nacional de Atenção Básica [Internet]. Brasília: Ministério da Saúde; 2012 [cited 2016 Apr 5]. Available from: http://189.28.128.100/dab/docs/publicacoes/geral/pnab.pdf

3. Leonello VM, Oliveira MAC. Competencies for educational activities in nursing. Rev Latino-Am Enfermagem [Internet]. 2008[cited 2017 Aug 8];16(2):177-83. Available from: http://www.scielo.br/pdf/rlae/v16n2/02.pdf

4. Gomes LB, Merhy EL. The popular education and the health care: a study from the work of Eymard Mourão Vasconcelos. Interface[Internet]. 2014 [cited 2017 May 15];18(2):1427-40. Available from: http://www.scielo.br/pdf/icse/v18s2/1807-5762-icse-18-s2-1427.pdf

5. Dias GAR, Lopes MMB. Educação e saúde no cotidiano de enfermeiras da atenção primária. Rev Enf UFSM [Internet]. 2013 [cited 2017 Apr 12];3(3):449-60. Available from: https://periodicos.ufsm.br/reufsm/article/view/7846.

6. Santos FPA, Acioli S, Rodrigues VP, Machado JC, Souza MS, Couto TA. Nurse care practices in the Family Health Strategy. Rev Bras Enferm [Internet]. 2016 [cited 2017 Apr 12];69(6):1124-31. Available from: http://www.scielo.br/pdf/reben/v69n6/en 00347167-reben-69-06-1124.pdf

7. Cervera DPP, Parreira BDM, Goulart BF. Educação em saúde: percepção dos enfermeiros da atenção básica em Uberaba (MG). Ciênc Saúde Colet [Internet]. 2011 [cited 2017 Aug 8];16(1):1547-54. Available from: http://www.scielo.br/pdf/csc/v16s1/ a90v16s1.pdf

8. Cruz PJSC, Vieira SCR, Massa NM, Araújo TAM, Vasconcelos ACCP. Desafios para a participação popular em saúde: reflexões a partir da educação popular na construção de conselho local de saúde em comunidades de João Pessoa, PB. Saúde Soc [Internet]. 2012[cited 2017 Aug 8];21(4):1087-100. Available from: http://www.scielo.br/pdf/sausoc/v21n4/v21n4a25.pdf

9. Roecker S, Budó MLD, Marcon SS. The educational work of nurses in the Family Health Strategy: difficulties and perspectives on change. Rev Esc Enferm USP [Internet]. 2012 [cited 2017 May 15];46(3):638-46. Available from: http://www.scielo.br/pdf/reeusp/ v46n3/en_16.pdf

10. Alves GG, Aerts D. As práticas educativas em saúde e a Estratégia Saúde da Família. Ciênc Saúde Colet[Internet]. 2011 [cited 2017 Aug 8];16(1):319-25. Available from: http://www.scielo.br/pdf/csc/v16n1/v16n1a34.pdf

11. Flisch TMP, Alves RH, Almeida TAC, Torres HC, Schall VT, Reis DC. Como os profissionais da atenção primária percebem e desenvolvem a Educação Popular em Saúde? Interface[Internet]. 2014 [cited 2017 Aug 8];18(2):1255-68. Available from: http:// www.scielo.br/pdf/icse/v18s2/1807-5762-icse-18-s2-1255.pdf

12. Vasconcelos EM, Vasconcelos MOD, Silva MO. A contribuição da Educação Popular Para a reorientação das práticas e da política de saúde no Brasil. Rev FAEEBA Educ Contemp [Internet]. 2015 [cited 2017 May 15];24(43):89-106. Available from: https://www. revistas.uneb.br/index.php/faeeba/article/viewFile/1311/886

13. Simon E, Jezine E, Vasconcelos EM, Ribeiro KSQS. Metodologias ativas de ensino-aprendizagem e educação popular: encontros e desencontros no contexto da formação dos profissionais de saúde. Interface[Internet]. 2014 [cited 2017 Jul 11];18(2):1355-64. Available from: http://www.scielo.br/pdf/icse/v18s2/1807-5762-icse-18-s2-1355.pdf

14. Perrenoud P. Construir as competências desde a escola. Porto Alegre: Artmed; 1999.

15. Delors J, (Org.). Educação: um tesouro a descobrir. 8a ed. São Paulo: Cortez; 2003 (Relatório para a UNESCO da Comissão Internacional sobre Educação para o Século XXI).

16. Chiesa AM, Westphal MF. A sistematização de Oficinas Educativas problematizadoras no contexto dos serviços de saúde. Rev Saúde Deb. 1995;46(1):19-22.

17. Fiorin JF. Elementos da análise de discurso. 13a ed. São Paulo: Contexto; 2005.

18. Leonello VM, Oliveira MAC. Integralidade do cuidado à saúde como competência educativa do enfermeiro. Rev Bras Enf 
[Internet]. 2010 [cited 2017 May 15];63(3):366-70. Available from: http://www.scielo.br/pdf/reben/v63n3/a03v63n3.pdf

19. Albuquerque PC, Stotz EN. Popular education in primary care: in search of comprehensive health care Interface[Internet]. 2004[cited 2017 Aug 8];8(15):259-74. Available from: http://www.scielo.br/pdf/icse/v8n15/a06v8n15.pdf

20. Oliveira LC, Ávila MMM, Gomes AMA, Sampaio MHLM. Popular participation in health education initiatives: challenges for primary healthcare professionals. Interface[Internet]. 2014 [cited 2017 Aug 8];18(2):1389-400. Available from: http://www.scielo. br/pdf/icse/v18s2/1807-5762-icse-18-s2-1389.pdf

21. Dias MSA, Parente JRF, Vasconcelos MIO, Dias FAC. Intersetorialidade e Estratégia Saúde da Família: tudo ou quase nada a ver? Ciênc Saúde Colet [Internet]. 2014 [cited 2017 Aug 8];19(11):4371-82. Available from: http://www.scielo.br/pdf/csc/v19n11/14138123-csc-19-11-4371.pdf

22. Sade PMC, Peres AM. Development of nursing management competencies: guidelines for continuous education services. Rev Esc Enferm USP [Internet]. 2015 [cited 2017 Aug 8];49(6):988-94. Available from: http://www.scielo.br/pdf/reeusp/v49n6/00806234-reeusp-49-06-0991.pdf

23. Peduzzi M, Carvalho BG, Mandú ENT, Souza GC, Silva JAM. Trabalho em equipe na perspectiva da gerência de serviços de saúde: instrumentos para a construção da prática interprofissional. Physis [Internet]. 2011 [cited 2017 Aug 8];21(2):629-46. Available from: http://www.scielo.br/pdf/physis/v21n2/a15v21n2.pdf

24. Paula M, Peres AM, Bernardino E, Eduardo EA, Sade PMC, Larocca LM. Características do processo de trabalho do enfermeiro da estratégia de saúde da família. Rev Min Enferm[Internet]. 2014 [cited 2017 Aug 8];18(2):454-70. Available from: http://reme.org. br/exportar-pdf/939/en_v18n2a15.pdf

25. Ano VM, Vannuchi MTO, Haddad MCFL, Pissinati PSC. Performance evaluation under the opinion of the nursing staff from a public university hospital. Ciênc Cuid Saúde [Internet]. 2015 [cited 2017 May 15];14(4):1403-10. Available from: http://periodicos. uem.br/ojs/index.php/CiencCuidSaude/article/view/27886/pdf_1

26. Oliveira VC. Comunicação, informação e participação popular nos Conselhos de Saúde. Saúde Soc [Internet]. 2004 [cited 2017 May 15];13(2):56-69. Available from: http://www.scielo.br/pdf/sausoc/v13n2/06.pdf

27. Coelho JS. Construindo a participação social no SUS: um constante repensar em busca de equidade e transformação. Saúde Soc [Internet]. 2012 [cited 2017 May 15];21(1):138-51. Available from: http://www.scielo.br/pdf/sausoc/v21s1/12.pdf 